Journal of the Scholarship of Teaching and Learning, Vol. 20, No. 3, December 2020, pp. 33-48.

doi: 10.14434/josotl.v20i3.27923

\title{
A Multi-disciplinary Mixed-Methods Study of Group Dynamics in Active Learning Space
}

\author{
Xiaoshan Zhu Gordy \\ University of Mississippi Medical Center \\ xgordy@umc.edu \\ Elizabeth O. Carr \\ University of Mississippi Medical Center \\ Lei Zhang \\ Mississippi Department of Health \\ Jessica H. Bailey \\ University of Mississippi Medical Center
}

\begin{abstract}
Active learning spaces emerged at the turn of the twenty-first century. The active learning space design represents not only an overbaul of traditional classrooms' physical appearances but also reflects a paradigm shift from teacher-centered learning to student-centered learning. Current available research mainly focused on student academic performance as well as student and faculty perceptions. Limited research has been conducted to investigate interactions at the student level to find out what interactions are taking place in the active learning spaces and how they affect student learning. This study employed a sequential exploratory mixed-methods design inquiring into student learning in an active learning space first through student focus group discussions and then with an online student survey. The major themes emerged from the focus group discussions were utilized to develop the online survey. The purpose of this survey was to cross-validate qualitative outcomes and further seek answers to unanswered questions triggered by qualitative findings. The qualitative data indicated that the spatial equity in the active learning space put students in positive mindsets and induced active classroom participation. The interconnected screens made it easy for students to view class content and collaborate with peers. The group work conducted in the space fostered mutual learning, promoted learning accountability and improved peer relations. The quantitative survey data on group dynamics validated and reinforced qualitative findings. This paper will help educators better understand student behaviors in the active learning spaces and better design space-appropriate pedagogical strategies.
\end{abstract}

Keywords: active learning space, spatial equity, technology, peer collaboration, peer interaction, group dynamics

\section{Introduction}

The classroom design of active learning spaces not only represents an overhaul of the physical appearance of the traditional learning environment but also implies a paradigm shift from the longestablished teacher-centered pedagogy to student-centered learning. In the traditional learning environment, rows of desks and chairs are arranged facing the lectern in the front - a design that has remained intact since the Middle Age (Park \& Choi, 2014) and reflects the primacy of teachers and the passive role of students in the classroom hierarchy (Siemens, 2008). An active learning space, instead, incorporates modern technology into a room design fueling a transformational vision of the student-centered learning. In general, it features movable round tables and chairs to allow flexible 
room configurations for different classroom activities, multiple interconnected screen displays for 360 degree unobstructed view, writable walls or portable white boards for constructive learning. It also has screen-sharing capabilities among in-room and personal devices for co-construction of knowledge through dynamic collaboration (Beichner, Saul, Allain, Deardorff, \& Abbott, 2000; Brooks, 2011; Dori \& Belcher, 2005; Lee, Morrone, \& Siering, 2018; Ramsay, Guo, \& Pursel, 2017). Figure 1 shows the general design differences between a traditional classroom and an active learning space.

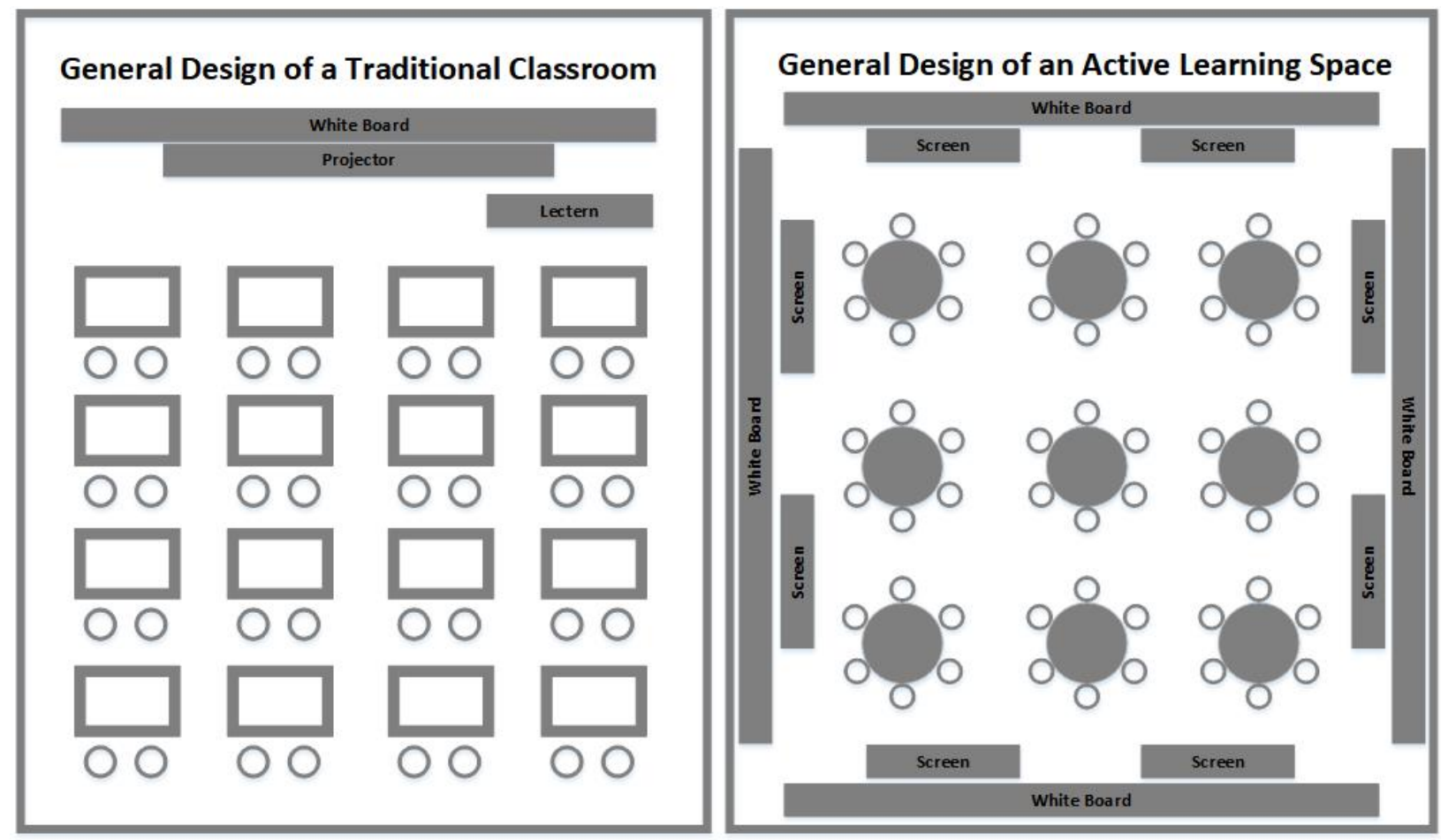

Figure 1. General Design of a traditional classroom and an active learning space.

Active learning spaces first emerged at the turn of the twenty-first century at North Carolina State University. Their SCALE-UP (Student-Centered Activities for Large Enrollment Undergraduate Programs) project utilized the active learning space design to facilitate studentcentered learning in undergraduate Physics courses (Beichner \& Saul, 2003; Saul, Deardorff, Abbott, Allain, \& Beichner, 2000). Since then, the active learning space design has been utilized by different universities in the United States including Massachusetts Institute of Technology (Dori \& Belcher, 2005), the University of Minnesota (Baepler, Brooks, Walker, \& Eds., 2014), Indiana University (Gibau, Kissel, \& Labode, 2019; Ricke, 2019), and the University of Iowa (Morrone et al., 2017; Van Horne \& Murniati, 2016), as well as institutions in Canada (Benoit, 2017; Gebre, Saroyan, \& Aulls, 2015), Korea (Park \& Choi, 2014), and China (Chiu, 2016).

Existing research on active learning spaces has evaluated academic performance (Brooks, 2011; Brooks \& Solheim, 2014; Dori \& Belcher, 2005; Gordy et al., 2018), instructor and student behavior (Brooks, 2012), most used utility functions (Poellhuber, Fournier St-Laurent, \& Roy, 2018), and perceptions of the space regarding different aspects of learning, teaching, and technology (Benoit, 2017; Chiu, 2016; Chiu \& Cheng, 2017; Connolly \& Lampe, 2016; Gordy, Jones, \& Bailey, 2018; Gordy, Zhang, Sullivan, Bailey, \& Carr, 2019; Lee, Morrone, \& Siering, 2018; Park \& Choi, 2014). Results from these studies showed that active learning spaces promote student engagement and peer interaction. However, limited research has been conducted to delve deep into what interactions are 
taking place in the active learning spaces and how they affect student learning. Gaining a deeper understanding of this topic will help educators better understand whether student behaviors in the active learning spaces differ from those in the traditional classrooms, and aid in better designing spaceappropriate pedagogical strategies.

\section{Methods}

The current study employed a sequential exploratory mixed-methods design (Hanson, Creswell, Clark, Petska, \& Creswell, 2005). In this design, qualitative and quantitative data are collected and analyzed in sequence with qualitative data collected and analyzed first, followed by quantitative data. This design is deemed to be the most effective for refining emerging themes from qualitative data and for making generalizations about a specific study population. To study the complex phenomena of student learning in the active learning space, we determined that this design is the most appropriate.

\section{Data Collection and Analysis}

Upon receiving approval from the Institutional Review Board at [Institution name], we reviewed the class schedules of our active learning space (called the Collaboratory - see Appendix 1) for the time period of fall 2017 to fall 2018. Four classes of students who took weekly classes in the Collaboratory were identified. These students were from four different disciplines in three different schools, including physical therapy (PT) and occupational therapy (OT) from the School of Health Related Professions, Dental Hygiene (DH) from the School of Dentistry, and Biostatistics and Data Science (BDS) from the School of Population Health. Students who took occasional classes in the Collaboratory were excluded. These students were first invited to participate in a semi-structured tenquestion focus group discussion. These questions were adapted from the student focus group instrument developed by the University of Minnesota's Learning Spaces Research Team (Brooks, 2011, 2012; Walker, Brooks, \& Baepler, 2011). A total of thirty-eight students were recruited - ten from PT, twelve from OT, eleven from DH, and five from BDS. Four separate focus group discussions were conducted with students in each discipline. The discussions were recorded and transcribed. Data were analyzed using Constant Comparative Method (CCM), a method widely used for qualitative analyses of focus group discussions (Glaser \& Strauss, 1967; Strauss, 1987). To increase the trustworthiness of the results, two authors analyzed the data separately and the codes and themes were compared. The final themes were discussed and agreed upon by all authors.

Based on the major themes that emerged from the qualitative data, an online survey was developed based on Karanxha \& Greenlee's study (2010). The survey included six demographic questions and eighteen questions triggered by the qualitative themes. A total of 204 students who had taken weekly classes in the Collaboratory from fall 2017 to spring 2019 were asked to participate and 177 responded, generating a response rate of $87 \%$. After eliminating two incomplete entries, survey data from 175 respondents were included in the data analysis. Independent-samples $t$-tests were performed on compare means on survey responses between traditional classrooms (TC) and the active learning space - Collaboratory using IBM SPSS 24.0.

Following the Good Reporting of a Mixed Methods Study (GRAMMS) framework (O'Cathain, Murphy, \& Nicholl, 2008), the qualitative and quantitative data were analyzed separately and then integrated in the interpretation phase. Equal priority was given to both (Hanson et al., 2005). Qualitative data generated original findings on the study topic and prompted more questions to be asked in the quantitative survey. Quantitative findings not only cross-validated qualitative outcomes but also further evaluated unanswered questions provoked by them. The study data collection and analysis procedures are shown in Figure 2. PT recording, OT Recording, DH recording and BDS

Journal of the Scholarship of Teaching and Learning, Vol. 20, No. 3, December 2020. josotl.indiana.edu 
recording refer to physical therapy, occupational therapy, dental hygiene, and biostatistics and data science student focus group discussion recordings respectively.

\section{Process Flow of Data Collection and Analysis}

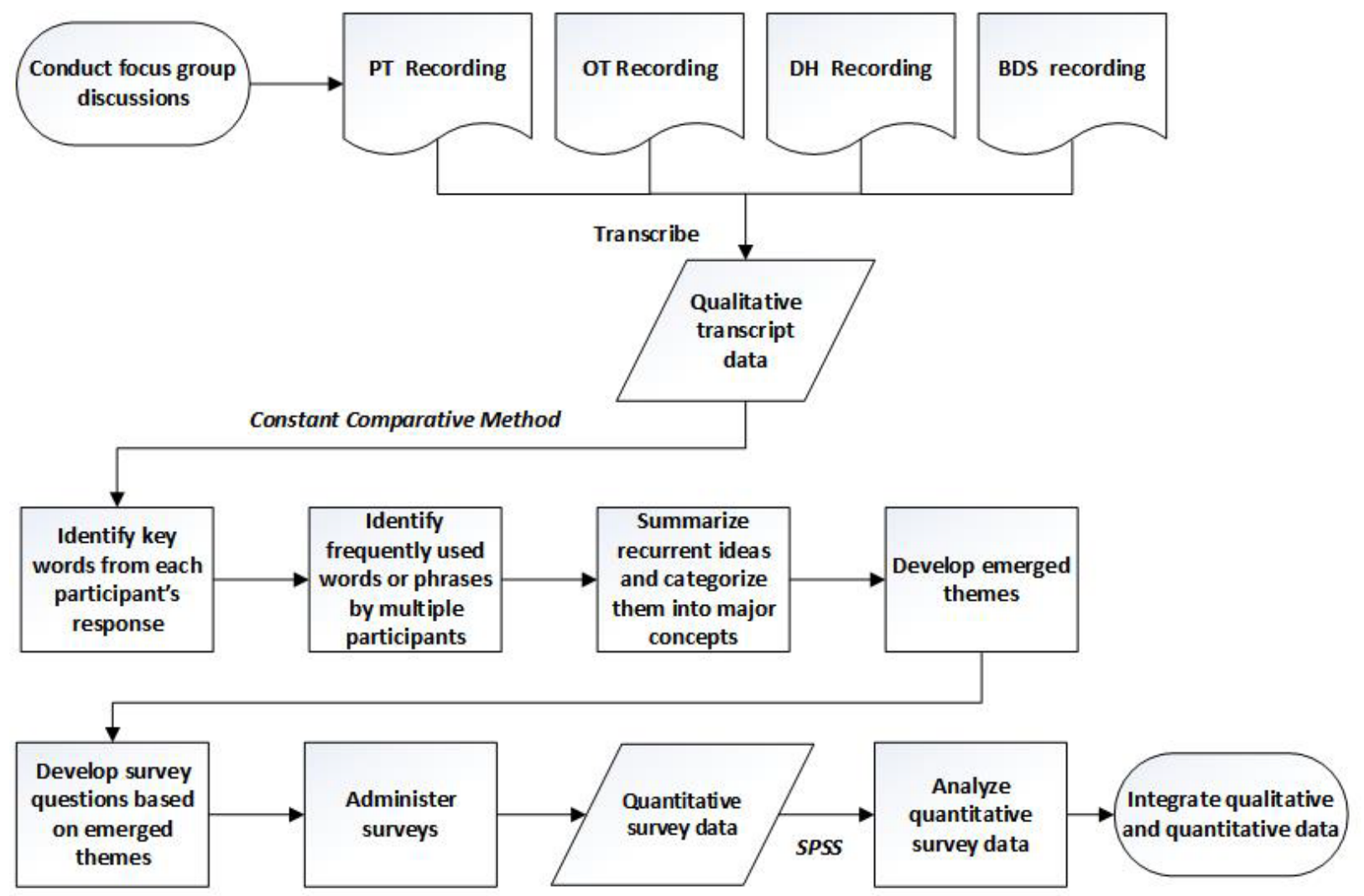

PT: Physical Therapy; OT: Occupational Therapy; DH: Dental Hygiene; BDS: Biostatistics and DataScience

Figure 2 Process flow of data collection and analysis.

\section{Results}

\section{Qualitative Findings}

The demographics of focus group discussion participants are shown in Table 1: the majority of them were female $(82 \%)$, white $(84 \%)$, aged between 21 and $25(82 \%)$ with the most recent GPA in the range of 3.5 to $4.0(53 \%)$.

Table 1 Demographics of focus group discussion participants $(\mathrm{N}=38)$

\begin{tabular}{lllll}
\hline Program & PT & OT & DH & BDS \\
$\mathrm{n}(\%)$ & $10(26 \%)$ & $12(32 \%)$ & $11(29 \%)$ & $5(13 \%)$ \\
Gender & Male & Female & & \\
$\mathrm{n}(\%)$ & $7(18 \%)$ & $31(82 \%)$ & & \\
Race & White & African-American & Asian & Hispanic/Latino \\
\hline
\end{tabular}

Journal of the Scholarship of Teaching and Learning, Vol. 20, No. 3, December 2020. josotl.indiana.edu 


\begin{tabular}{|c|c|c|c|c|c|}
\hline $\mathrm{n}(\%)$ & $32(84 \%)$ & $1(3 \%)$ & $4(11 \%)$ & $1(3 \%)$ & \\
\hline Age (yr) & $21-25$ & $26-29$ & 30 or older & & \\
\hline $\mathrm{n}(\%)$ & $31(82 \%)$ & $2(5 \%)$ & $5(13 \%)$ & & \\
\hline $\begin{array}{l}\text { Recent } \\
\text { GPA }\end{array}$ & $2.5 \leq \mathrm{GPA}<3.0$ & $3.0 \leq \mathrm{GPA}<3.5$ & $3.5 \leq \mathrm{GPA}<4.0$ & 4.0 & Unknown \\
\hline $\mathrm{n}(\%)$ & $2(5 \%)$ & $8(21 \%)$ & $20(53 \%)$ & $7(18 \%)$ & $1(3 \%)$ \\
\hline
\end{tabular}

The themes that emerged from the qualitative data are organized in three categories: spatial equity, technology, and peer collaboration and interactions.

Spatial equity. The casual non-hierarchical learning space generates a positive psychological climate conducive to learning.All furniture in the Collaboratory is movable and spatially spread out with no hierarchy as seen in traditional classrooms with rows of tables and chairs arranged facing the lectern - the symbol of authority - in the front. The swivel chairs were favored by many. One student said, "Here you are all either at a circular table, or at a table where you all are equally the same, spaced apart. Something else - I am shorter than an average person, so I concentrate there more because the chairs are more comfortable. I have somewhere to put my feet. I am not like shoved under this desk where my feet don't touch the ground... when you are more comfortable, you are more likely to participate". Many others commented on the comfortable and relaxing atmosphere. One said, "Because it is so relaxing in there, I think it kind of helped me overcome my apprehension about programming". Another added, "The room is very comfortable. So it doesn't feel clinical. I mean, it feels very warm. So I feel comfortable in there, which helps.” Quite a few students even mentioned that they felt more excited about going to class and learning about the course subjects. Typical quotes include, "We were always excited to go to class. If it's in that room, we were like, 'we are in the cool room today'. We really like going there"; "I know I feel better about radiology II because maybe it's the classroom that made me feel more excited to go."

Non-threatening atmosphere triggered more student-generated questions and active participation. It was noted from classroom observations in previous studies (Gordy et al., 2018; Gordy et al., 2019) that students in the Collaboratory oftentimes sat at a table as a group and did group work together as assigned by the instructor. Being in a group in a non-threatening atmosphere encouraged students to speak up in class. One said, "In a traditional classroom, when you ask a question or you add something, the center is on you. So you are less likely to say something. In the Collaboratory you are in a group, you kind of speak as one voice to the teacher"; another said that "I think personally I feel more prompt to ask questions and to talk than I do when we are in (traditional) class. Even if I do have a question that comes to my head that could help me learn better, but I am like 'nah, I don't want all 45 people listening. I will just ask later'. But if we are in that setting, I just talk more and think more."

\section{Technology}

Screen proximity enabled visual convenience of learning and better engaged students. In the Collaboratory students had 360-degree unobstructed views of the screens located on each table and wall, which allowed easy visual access to learning materials and made it easy for students to stay engaged. Typical quotes included: "I feel like since the screen is right in front of you, you have more individual time to look at it and think about it more than one that is far away on a big screen"; "Being that close to the screen, subconsciously I feel like it's my screen. I can interact with it, and so if I want to see what

Journal of the Scholarship of Teaching and Learning, Vol. 20, No. 3, December 2020. josotl.indiana.edu 
happens when I change this thing, I just say it and he (the instructor) will do it. So that keeps me engaged a little bit, you know, as opposed to like, if you are very far away from the screen, you are kind of just watching someone else manipulate the stuff on the screen"; "The advantage for me of being in the Collaboratory because I sit right next to the screen. I think the environment in there is inviting...I feel like the technology is conducive to what I need to learn from the class. In another one of our classes, we use computer software. Sometimes it is a little harder to focus because I am so far away from the screen, so I have to bring my own computer. And by the time I get all that together, he may have moved on to something else. But in the Collaboratory, you know, pretty much follow along with the instructor because I am so close to the screen. So, it does help me stay focused and engaged."

Screen sharing capability allowed for easy and effective collaboration. In the Collaboratory, the students could hook up their own devices to the screens and project the content to just their screens or to all. Students found it easier and more effective to collaborate with the screen sharing technology. One student said, "There are times we work in groups and do case studies, you know, (the instructor) gives us 20 minutes to work on a case study, um, but it kind of turns into 7 people crowded around one tiny laptop, we can't see what's going on. With the same activity in the Collaboratory where we could all look at the same screen together, it would be more effective". Another student said, "I think with one of our classes we had to use the technology a lot more than a lot of other classes, I got more, I mean, personally, I got more excited about going there because we could all work on it together...she could show us something and we can do it right then on our own computers or hook it up to the TV, or one of us could do it. We can all follow along pretty easily, rather than a big projector screen in the front of the classroom."

\section{Peer collaboration and interaction}

\section{Hands-on group work conducted in the active learning space facilitated mutual learning and fostered idea} generation. The students identified group work over and over again whenever they were giving examples to answer questions. Through the group work, they tended to co-construct knowledge or build upon each other's expertise. One student said, "Going back to systematic review and poster design, a lot of ideas we had weren't necessarily my idea...they would give an idea, I would bounce something, adding on to that idea, or something making me think in a different way. So that would spark more ideas. It kind of went around a circle like that. So I think it definitely helped make me more creative in there". Another student thought the size of the tables in the room was conducive to group collaboration: "I think the size of the tables really fosters more of a group environment. When we get into group work in a regular classroom, we tend to have bigger groups because that's just easier to manage. When we are in the groups of 5 people each around the monitor and around each other (in the Collaboratory), we are able to bounce ideas off each other in that smaller, more intimate group. I think, maybe, that would improve my critical thinking because we are able to easily bounce ideas off each other."

Peer collaboration and interaction in the active learning space induced higher extrinsic motivation and learning accountability and reduced the occurrence of social loafing. Social loafing refers to the phenomenon in which certain students fail to contribute during group work and rely on others do the work for them (Shimazoe \& Aldrich, 2010). In the Collaboratory, since the visual and spatial convenience made it possible for everyone to participate, it fostered a higher peer motivation to contribute to the group work and reduced the social loafing of some students. One student said, "It is ... not like a competition thing but if I were doing an independent study, we were all brainstorming, on our own

Journal of the Scholarship of Teaching and Learning, Vol. 20, No. 3, December 2020. josotl.indiana.edu 
in a classroom setting, I might get distracted, not really challenge myself. But when I'm in a group with other people, they are all throwing out these ideas, I feel like I need to contribute. You know, maybe not a competition, but I just need to pull my own weight and say my ideas too...You definitely don't want to be the weakest link of the group". Another student commented, "I think working with a group kind of forced you to keep up, because you don't want to feel like that odd person who is just not really contributing anything. So, trying to stay up, trying to provide ideas even though they may not be the best, something different to offer the group, just trying to find out a way to help out anyway you can."

The environment broke the norm of homophily and promoted reciprocated peer relations. Homophily refers to the phenomenon in which students tend to make friends with peers whom they share similar demographic, social, behavioral, and other characteristics (Adler \& Adler, 1995). In a traditional classroom setting, students tend to sit and interact with their homogeneous friend group (Miller McPherson, Lynn Smith-Lovin, \& James M. Cook, 2001). However, in the Collaboratory, students felt that it was easier to get out of comfort zone and interact more with peers outside their immediate friend group. Quite a few students stated that they sat with people not in their usual friend group. One said, "A lot of times if you are just in a lecture class, they will say 'get in a group'. Before you will get up and you gravitate towards people in the same group every time but I was in groups with different people throughout the Collaboratory"; Another student said, "In the Collaboratory, me and Chelsea (pseudo name) were at the same table. In a different room, we weren't at the same table because we wouldn't naturally go to the same table. So the Collaboratory room put us together and we were able to, like, she was listening to conversations that we had, that she wouldn't normally know what we did on the weekend...you get to know people better, like hang out in the Collaboratory room that you don't really do in a different classroom."

The increased interactions with heterogeneous groups of peers promoted overall peer relations in class. One quote said, "Going to the Collaboratory, I might have gotten to know a few other classmates that I didn't know as well ... when you compare to just sitting in rows"; "I can see that in normal traditional classroom, we are separate from each other. And here we sit close to five or six people...it helps to be in a good relationship rather than the traditional classroom". Students also became more aware of each other's feelings when sitting in small groups. One said, "We know each other because we are in the same program but we can kind of sense when one of us is struggling ... and so one of my classmates sitting at the table with me will see the look, 'are you okay?'. And then when people get something, you can hear the excitement when they get it. So it is kind of encouraging to you too. So it is kind of like we feed off each other's energy better, versus a traditional classroom where we are so separated. It's just like everybody is just kind of doing their own thing, paying attention or not."

\section{Quantitative Findings}

As group work, collaboration and interaction were repeatedly mentioned in focus group discussions, a quantitative survey was developed to evaluate group dynamics. Group dynamics was a term used to describe how social processes impact group members in regard to the interdependence of each individual in the group, social interactions, interrelationships, and their capability as a group to accomplish its goals (Forsyth, 1999). The survey included twenty-four questions - six demographical questions and eighteen questions on 5-point Likert scale concerning group dynamics. In order to gain a better understanding of group dynamics in the Collaboratory when compared to the traditional classroom setting, the participants were asked to respond to each of the eighteen questions twice, once in the context of traditional classrooms and once the Collaboratory. For the purpose of this paper, only items related to the qualitative findings were reported here.

Journal of the Scholarship of Teaching and Learning, Vol. 20, No. 3, December 2020. josotl.indiana.edu 
Scales for all constructs in the survey had over 0.9 Cronbach's alpha values (see Appendix 2). The overall survey had a Cronbach's alpha of 0.936, which indicates strong reliability and internal consistency of the instrument (Tavakol \& Dennick, 2011).

Independent-samples t-tests were performed to compare students' perceptions of group dynamics in the Collaboratory and traditional classrooms. Table 2 shows the results of group dynamics survey responses.

Table 2 Group Dynamics Survey Responses

* ALS (active learning space) - Collaboratory; TC - traditional classrooms)

\begin{tabular}{|c|c|c|c|c|}
\hline Survey Questions & $\begin{array}{l}\text { Classroom } \\
\text { Type }\end{array}$ & Mean & $\begin{array}{l}\text { Mean } \\
\text { Difference } \\
\text { (ALS-TC) }\end{array}$ & $\mathrm{P}$-value \\
\hline \multirow{2}{*}{$\begin{array}{l}\text { 1. The atmosphere in the classroom makes me } \\
\text { feel comfortable and relaxed. }\end{array}$} & $\mathrm{TC}$ & 3.85 & \multirow[t]{2}{*}{0.51} & \multirow[t]{2}{*}{$<0.001$} \\
\hline & ALS & 4.36 & & \\
\hline \multirow{2}{*}{$\begin{array}{l}\text { 2. I feel comfortable asking my instructor } \\
\text { questions and seeking help from him/her in }\end{array}$} & $\mathrm{TC}$ & 3.89 & \multirow[t]{2}{*}{0.53} & \multirow[t]{2}{*}{$<0.001$} \\
\hline & ALS & 4.42 & & \\
\hline \multirow{2}{*}{$\begin{array}{l}\text { 3. I feel comfortable asking peers questions and } \\
\text { seeking help from them in class. }\end{array}$} & $\mathrm{TC}$ & 3.93 & \multirow[t]{2}{*}{0.69} & \multirow[t]{2}{*}{$<0.001$} \\
\hline & ALS & 4.62 & & \\
\hline \multirow{2}{*}{$\begin{array}{l}\text { 4. During group work, each member of the group } \\
\text { has the freedom to express opinions. }\end{array}$} & $\mathrm{TC}$ & 3.93 & \multirow[t]{2}{*}{0.66} & \multirow[t]{2}{*}{$<0.001$} \\
\hline & ALS & 4.59 & & \\
\hline \multirow{2}{*}{$\begin{array}{l}\text { 5. During group work, my group members build } \\
\text { upon each other's knowledge through }\end{array}$} & $\mathrm{TC}$ & 3.83 & \multirow[t]{2}{*}{0.75} & \multirow[t]{2}{*}{$<0.001$} \\
\hline & ALS & 4.58 & & \\
\hline \multirow{2}{*}{$\begin{array}{l}\text { 6. During group work, each group member's } \\
\text { ideas are listened to and considered by other } \\
\text { members in my group. }\end{array}$} & $\mathrm{TC}$ & 3.90 & \multirow[t]{2}{*}{0.35} & \multirow[t]{2}{*}{$<0.001$} \\
\hline & ALS & 4.25 & & \\
\hline \multirow{2}{*}{$\begin{array}{l}\text { 7. During group work, everyone in the group } \\
\text { actively participate and contribute. }\end{array}$} & $\mathrm{TC}$ & 3.57 & \multirow[t]{2}{*}{0.80} & \multirow[t]{2}{*}{$<0.001$} \\
\hline & ALS & 4.37 & & \\
\hline \multirow{2}{*}{$\begin{array}{l}\text { 8. The technology in the classroom makes it easy } \\
\text { to collaborate on group tasks. }\end{array}$} & TC & 2.86 & \multirow[t]{2}{*}{1.79} & \multirow[t]{2}{*}{$<0.001$} \\
\hline & ALS & 4.65 & & \\
\hline \multirow{2}{*}{$\begin{array}{l}\text { 9. My group members collaborate effectively to } \\
\text { complete our group tasks. }\end{array}$} & TC & 3.85 & \multirow[t]{2}{*}{0.62} & \multirow[t]{2}{*}{$<0.001$} \\
\hline & ALS & 4.47 & & \\
\hline \multirow{2}{*}{$\begin{array}{l}\text { 10. In working together to solve problems, my } \\
\text { group has been able to identify the important } \\
\text { issues and generate several possible solutions. }\end{array}$} & $\mathrm{TC}$ & 3.99 & \multirow[t]{2}{*}{0.38} & \multirow[t]{2}{*}{$<0.001$} \\
\hline & ALS & 4.37 & & \\
\hline \multirow{2}{*}{$\begin{array}{l}\text { 11. I have increased my knowledge about } \\
\text { important topics since working in groups with }\end{array}$} & $\mathrm{TC}$ & 4.07 & 0.28 & $<0.001$ \\
\hline & ALS & 4.35 & & \\
\hline 12. I have developed closer relationships with & TC & 3.93 & 0.48 & $<0.001$ \\
\hline others in my group. & ALS & 4.41 & & \\
\hline 13. I tend to socialize and work with peers outside & TC & 3.82 & 0.21 & 0.018 \\
\hline my friend group. & ALS & 4.03 & & \\
\hline 14. I have a sense of ownership over what my & $\mathrm{TC}$ & 3.81 & 0.33 & $<0.001$ \\
\hline group does. & ALS & 4.14 & & \\
\hline 15. I have a sense of belonging to the group. & $\mathrm{TC}$ & 3.99 & 0.32 & $<0.001$ \\
\hline & ALS & 4.31 & & \\
\hline
\end{tabular}




\section{Discussion}

The design of any space can influence the behaviors of individuals within the space (Orr, 2004; Weinstein, 1979). The spatial equity made possible by movable furniture and advanced technology in the active learning space not only invites open interpretative use to perceived learning needs but also empowers student flexibility for learning (Monohan, 2002). In this study, the students believed that the physical environment of the Collaboratory placed them in positive mindsets for learning. They felt comfortable, relaxed, and more likely to speak up and actively participate in class. This is consistent with our previous Collaboratory studies (Gordy et al., 2018; Gordy et al., 2019) and a few of others (Brooks, 2012; Park \& Choi, 2014; Paul Baepler \& Walker, 2014; Rands \& Gansemer-Topf, 2017). The significant differences from the quantitative data, specifically survey questions $1,2,3,4$, 7 shown in Table 2, show the benefits of the active learning space design and support this finding. Positive mindsets for learning (Boekaerts, 2011; Efklides, Schwartz, \& Brown, 2018; Fredrickson, 1998; Fredrickson \& Joiner, 2002; Graetz, 2006; Williams, Childers, \& Kemp, 2013) and active participation (Pratton \& Hales, 1986; Smith \& Cardaciotto, 2011; Warren, 2016) have been reported to have positive impact on student learning.

Technology is viewed as a robust tool for transforming learning, promoting collaboration, and leveling opportunities for students (U.S. Department of Education, 2016). The interconnected screens in the Collaboratory removed the visual barriers in the room and promoted effective collaboration due to the close screen proximity and screen sharing capability. Survey questions 8 and 9 shown in Table 2 corroborate the qualitative theme of technology. These interconnected screens not only have consistently been favored by students in different studies but have also has been reported to be conducive to conducting active learning activities, engaging students, promoting peer interactions, and improving team performance on classroom assignments (Benoit, 2017; Chiu, 2016; Gordy et al., 2019; Park \& Choi, 2014; Stoltzfus \& Libarkin, 2016).

One of the main purposes of the active learning space design is to enable active learning (Baepler et al., 2014; R. Beichner et al., 2008; Dori \& Belcher, 2005). In practice, active learning often involves doing hands-on group work (Barkley, 2010; Bonwell \& Eison, 1991). Survey questions 5,6,7,10 and 11 assessed students' perceptions on different aspects of group work. The significant higher means of the Collaboratory demonstrated its superiority in supporting group work. In this study, students repeatedly stated in the focus group discussions how they collaborated through group work, how they learned from each other, and how they bounced ideas off each other to come up with new ones. Studies have reported that this mutual learning process through group work has several benefits. It encourages peer interaction, promotes students' active involvement in learning activities, provides them with opportunities to user higher-order thinking skills to complete tasks, increases confidence, decreases anxiety, facilitates higher academic performance and satisfaction, and enhances the development of important skills such as critical thinking, self-directed learning, interpersonal communication, team work, and project management (Boud \& Lee, 2005; Brookfield, 1987; Broscious \& Saunders, 2001; Stone, Cooper, \& Cant, 2013). In addition, studies have shown that through peer collaboration and interaction in group work students tend to take more responsibility in their own learning, monitor their strengths and weaknesses in the learning process and make conscious efforts towards improvement (Boud, Cohen, \& Sampson, 2001; Williamson, 2007). This reaffirms why students in the current study were showing higher motivation and learning accountability, and a lower tendency for social loafing. Studies by Chiu (2016), Rands \& Gansemer-Topf (2017), Park \& Choi (2014) are also consistent with our findings.

One of the unanticipated results from the increased collaboration and interactions in the active learning space is closer relationships among students. Survey questions Q12-15 support this qualitative finding and confirm previous studies (Chiu, 2016; Connolly \& Lampe, 2016; Gordy et al, 2018; Park

Journal of the Scholarship of Teaching and Learning, Vol. 20, No. 3, December 2020. josotl.indiana.edu 
\& Choi, 2014). It is worth noting that students in the current active learning space tended to break the norm of interacting with a homegenous group and socialized outside their immediate friend group, the opposite of what has been observed in the traditional settings (M. McPherson, L. Smith-Lovin, \& J. M. Cook, 2001). Considering the diversity of today's workforce, the experiences and skills students gain from collaborating and interacting with a heterogenous group should be conducive to improving interpersonal communication capabilities.

Group work is one of the most important and commonly used teaching techniques in the active learning spaces (Baepler et al., 2014; Beichner et al., 2000; Dori \& Belcher, 2005; Gordy et al., 2018). Having students work in groups increases peer interaction, promotes the generation of varied ideas, develops collaboration and critical thinking skills, and fosters learner accountability (Hansen, 2006; Harmer, 2007; Scrivener, 2011). It also helps create a supportive atmosphere for idea generation and sharing, a sense of belonging, and peer bonds that would not otherwise develop (Burdett \& Hastie, 2009; Gorse \& Sanderson., 2007). These benefits of group work were manifested in our emerged qualitative themes. The group dynamics survey in this study were designed to delve deeper into group work within the active learning space to determine what was happening within the groups, and better understand how the students interacted with their peers. The overall higher mean scores of the Collaboratory substantiate the qualitative findings and further confirm the instrumental value of active learning space in student learning.

One important limitation of the study is that this research was based on the only active learning space at our institution. It may be beneficial to conduct similar studies in different active learning spaces as they become available. Secondly, this study did not examine the faculty's perspectives on group work to obtain their insights. Future studies should inquire into group dynamics from both faculty and students' perspectives. Overall, this study employed a mixed-methods approach to increase the rigor of the study design, multi-coders analyzed the qualitative data to increase the trustworthiness, and followed the best practice GRAMMS for data reporting. It probed an area of research of active learning spaces that had not been sufficiently explored so far and contributed new knowledge to the field.

\section{Conclusion}

This sequential exploratory mixed-methods study inquired into student learning in an active learning space through student focus group discussions and an online student survey. Themes from focus group discussions indicated that the spatial equity in the active learning space put students in positive mindsets and induced active classroom participation. The interconnected screens made it easy for students to view class content and collaborate with peers. The group work conducted in the space fostered mutual learning, promoted learning accountability and improved peer relations. The online study survey on group dynamics validated and reinforced qualitative findings.

Journal of the Scholarship of Teaching and Learning, Vol. 20, No. 3, December 2020. josotl.indiana.edu 


\section{Appendix}

\section{Appendix 1. Collaboratory Pictures.}
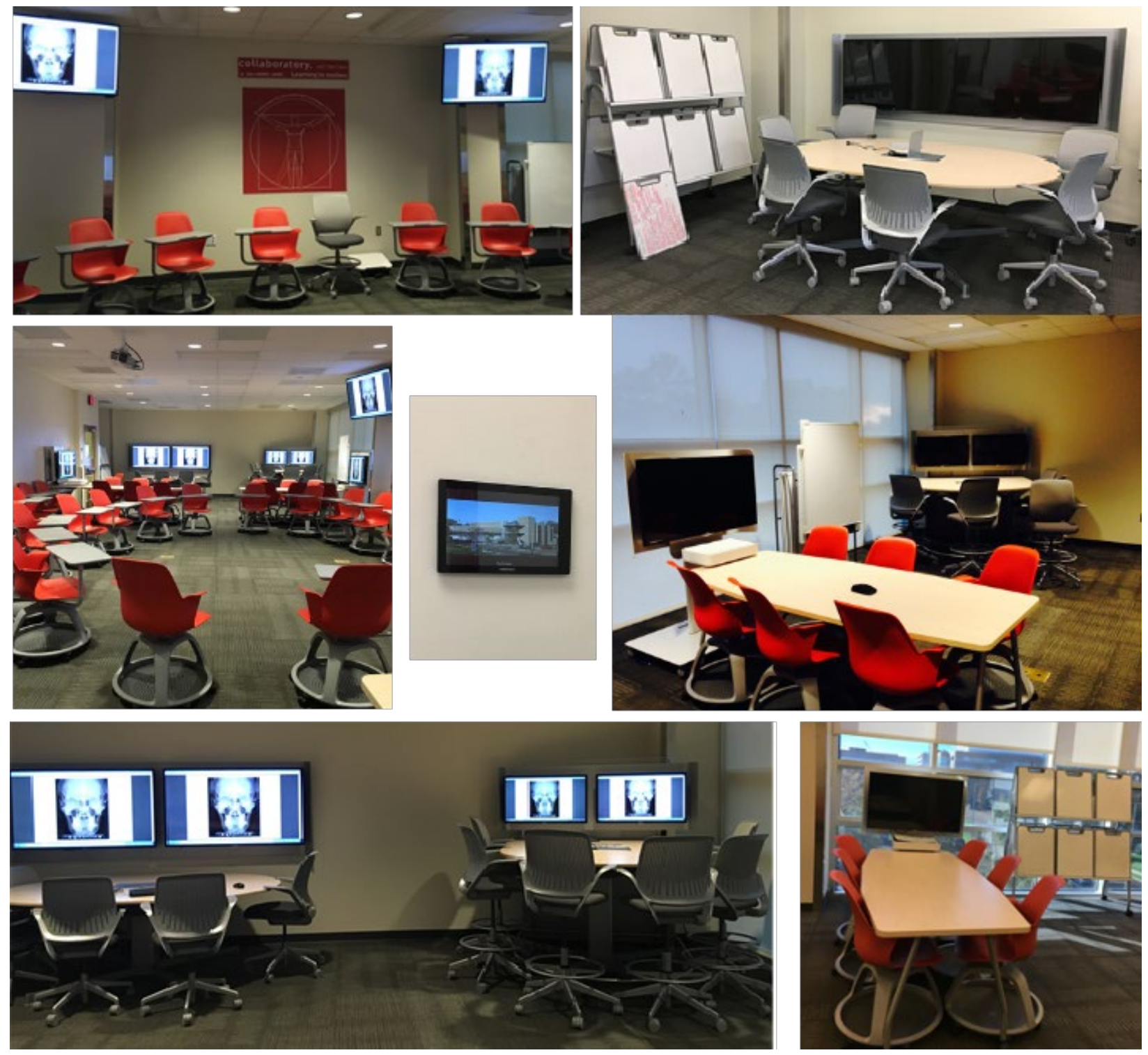


\section{Appendix 2. Cronbach's Alpha Item-Total Statistics.}

\begin{tabular}{|c|c|c|c|c|c|}
\hline Survey Questions & $\begin{array}{c}\text { Scale Mean if } \\
\text { Item Deleted }\end{array}$ & $\begin{array}{c}\text { Scale Variance } \\
\text { if Item } \\
\text { Deleted }\end{array}$ & $\begin{array}{c}\text { Corrected } \\
\text { Item-Total } \\
\text { Correlation }\end{array}$ & $\begin{array}{c}\text { Squared } \\
\text { Multiple } \\
\text { Correlation }\end{array}$ & $\begin{array}{c}\text { Cronbach's } \\
\text { Alpha if Item } \\
\text { Deleted }\end{array}$ \\
\hline AtmosphereComfortable & 69.3324 & 102.316 & .552 & .376 & .935 \\
\hline AskingIntructorQuestio & 69.2799 & 101.190 & .536 & .348 & .935 \\
\hline SeekHelpFromPeers & 69.1574 & 100.057 & .661 & .500 & .933 \\
\hline FreedomToExpress & 69.1603 & 98.468 & .730 & .617 & .931 \\
\hline BuildUponEachOther & 69.2303 & 97.488 & .792 & .697 & .930 \\
\hline EveryoneParticipates & 69.4665 & 96.232 & .763 & .651 & .930 \\
\hline IdeasValued & 69.3528 & 100.235 & .660 & .547 & .933 \\
\hline TechEasyCollaborate & 69.6880 & 94.788 & .626 & .491 & .935 \\
\hline GroupWorkOwnPace & 69.4490 & 98.272 & .663 & .528 & .933 \\
\hline GroupCollaborateEffecti & 69.2741 & 98.808 & .784 & .674 & .930 \\
\hline GroupProblemSolving & 69.2478 & 101.935 & .737 & .597 & .932 \\
\hline GroupWorkIncreaseKn & 69.2245 & 102.169 & .683 & .573 & .933 \\
\hline CloserRelationships & 69.2624 & 100.112 & .743 & .607 & .931 \\
\hline LearningEnjoyable & 69.7230 & 97.628 & .604 & .443 & .934 \\
\hline PeersOutsideFriendGro & 69.5015 & 102.578 & .489 & .359 & .936 \\
\hline InfluenceOverGroup & 69.3411 & 102.190 & .638 & .553 & .933 \\
\hline SenseOfOwnership & 69.4577 & 102.916 & .536 & .432 & .935 \\
\hline SenseOfBelonging & 69.2857 & 101.094 & .724 & .665 & .932 \\
\hline
\end{tabular}

\section{References}

Adler, P. A., \& Adler, P. (1995). Dynamics of Inclusion and Exclusion in Preadolescent Cliques. Social Psychology Quarterly, 58(3), 145-162.

Baepler, P., Brooks, D. C., Walker, J. D., \& Eds. (2014). Active Learning Spaces: New Directions in Teaching and Learning, No.137. San Francisco, CA: Jossey-Bass.

Barkley, E. F. (2010). Student engagement techniques: A bandbook for college faculty. San Francisco, CA: Jossey-Bass.

Beichner, R., \& Saul, J. (2003). Introduction to the SCALE-UP (Student-Centered Activities for Large Enrollment Undergraduate Programs) Project.

Beichner, R., Saul, J., S Abbott, D., J Morse, J., Deardorff, D., Allain, R., . . S Risley, J. (2008). Student-centered activities for large enrollment undergraduate programs (SCALE- UP). Research-based Reform of University Physics, 1.

Beichner, R. J., Saul, J. M., Allain, R. J., Deardorff, D. L., \& Abbott, D. S. (2000). Introduction to SCALE-UP: Student-Centered Activities for Large Enrollment University Physics. Retrieved from http://search.ebscohost.com/login.aspx?direct=true\&db=eric\&AN=ED459062\&site $=$ ehos t-live

Benoit, A. (2017). Monitoring Implementation of Active Learning Classrooms at Lethbridge College, 2014-2015. Journal of Learning Spaces, 6(1), 14-25. 
Boekaerts, M. (2011). Emotions, emotion regulation, and self-regulation of learning. In B. J. Zimmerman \& D. H. Schunk (Eds.), Handbook of self-regulation of learning and performance. (pp. 408-425). New York, NY: Routledge/Taylor \& Francis Group.

Bonwell, C. C., \& Eison, J. A. (1991). Active Learning: Creating Excitement in the Classroom. 1991 ASHEERIC Higher Education Reports. Washington D. C.: Association for the Study of Higher Education - Eric Clearinghouse on Higher Education.

Boud, D., Cohen, R., \& Sampson, J. (2001). Peer Learning in Higher Education: Learning from \& with Each Other.

Boud, D., \& Lee, A. (2005). "Peer Learning" as Pedagogic Discourse for Research Education. Studies in Higher Education, 30(5), 501-516.

Brookfield, S. D. (1987). Developing critical thinkers. San Franciso, CA: Jossey-Bass.

Brooks, D. C. (2011). Space matters: The impact of formal learning environments on student learning. British Journal of Educational Technology, 42(5), 719-726.

Brooks, D. C. (2012). Space and consequences: The impact of different formal learning spaces on instructor and student behavior. Journal of Learning Spaces, 1(2).

Brooks, D. C., \& Solheim, C. A. (2014). Pedagogy Matters, Too: The Impact of Adapting Teaching Approaches to Formal Learning Environments on Student Learning. New Directions for Teaching \& Learning, 2014(137), 53-61. https://doi.org/10.1002/tl.20085

Broscious, S. K., \& Saunders, D. J. (2001). Peer coaching. Nurse Educ, 26(5), 212-214.

Burdett, J., \& Hastie, B. (2009). Predicting Satisfaction with Group Work Assignments. Journal of University Teaching \& Learning Practice, 6(1), 61-71.

Chiu, P. H. P. (2016). A Technology-Enriched Active Learning Space for a New Gateway Education Programme in Hong Kong: A Platform for Nurturing Student Innovations. Journal of Learning Spaces, 5(1), 52-60.

Chiu, P. H. P., \& Cheng, S. H. (2017). Effects of active learning classrooms on student learning: a two-year empirical investigation on student perceptions and academic performance. Higher Education Research \& Development, 36(2), 269-279. https://doi.org/10.1080/07294360.2016.1196475

Connolly, A., \& Lampe, M. (2016). How an Active Learning Classroom Transformed IT Executive Management. Information Systems Education Journal, 14(1), 15-27.

Dori, Y. J., \& Belcher, J. (2005). How Does Technology-Enabled Active Learning Affect Undergraduate Students' Understanding of Electromagnetism Concepts? Journal of the Learning Sciences, 14(2), 243-279.

Efklides, A., Schwartz, B. L., \& Brown, V. (2018). Motivation and affect in self-regulated learning: Does metacognition play a role? In D. H. Schunk \& J. A. Greene (Eds.), Handbook of selfregulation of learning and performance., 2nd ed. (pp. 64-82). New York, NY: Routledge/Taylor \& Francis Group.

Forsyth, D. R. (1999). Group dynamics (3rd ed. ed.). Belmont, Calif. ;: Brooks/Cole, Wadsworth.

Fredrickson, B. L. (1998). What Good Are Positive Emotions? Review of General Psychology, 2(3), 300319. https://doi.org/10.1037/1089-2680.2.3.300

Fredrickson, B. L., \& Joiner, T. (2002). Positive Emotions Trigger Upward Spirals Toward Emotional Well-Being. Psychological Science (0956-7976), 13(2), 172. https://doi.org/10.1111/1467-9280.00431

Gebre, E., Saroyan, A., \& Aulls, M. W. (2015). Conceptions of Effective Teaching and Perceived Use of Computer Technologies in Active Learning Classrooms. International Journal of Teaching and Learning in Higher Education, 27(2), 204-220.

Journal of the Scholarship of Teaching and Learning, Vol. 20, No. 3, December 2020. josotl.indiana.edu 
Gibau, G., Kissel, F., \& Labode, M. (2019). Starting with the Space: Integrating Learning Spaces and Technologies. Journal of Teaching and Learning with Technology, 8(1), 17-32. https://doi.org/10.14434/jotlt.v8i1.26743

Glaser, B. G., \& Strauss, A. (1967). The Discovery of Grounded Theory: Strategies for Qualitative Research. Chicago, IL: Aldine Publishing Co.

Gordy, X. Z., Jones, E. M., \& Bailey, J. H. (2018). Technological Innovation or Educational Evolution? A Multidisciplinary Qualitative Inquiry into Active Learning Classrooms. Journal of the Scholarship of Teaching and Learning, 18(2), 1-23.

Gordy, X. Z., Zhang, L., Sullivan, A. L., Bailey, J. H., \& Carr, E. O. (2019). Teaching and Learning in an Active Learning Classroom: A Mixed-Methods Empirical Cohort Study of Dental Hygiene Students. Journal of Dental Education, JDE.019.026. https://doi.org/10.21815/JDE.019.026

Gordy, X. Z., Zhang, L., Sullivan, A. L., Haynie, L., Richards-Moore, L., \& Bailey, J. H. (2018). A Multi-disciplinary Empirical Investigation of Active Learning Classroom's Effects on Student Learning. Interdisciplinary Education and Psychology, 2(1), 3.

Gorse, C. A., \& Sanderson., A. M. (2007). Exploring group work dynamics. Paper presented at the In Proceedings 23rd annual ARCOM conference, Belfast, UK.

Graetz, K. A. (2006). The psychology of learning environments. EDUCAUSE Review, 41(6), 60-75.

Greenlee, B. J., \& Karanxha, Z. (2010). A Study of Group Dynamics in Educational Leadership Cohort and Non-Cohort Groups. Journal of Research on Leadership Education, 5(11), 357-382.

Hansen, R. S. (2006). Benefits and Problems With Student Teams: Suggestions for Improving Team Projects. Journal of Education for Business, 82(1), 11-19. https://doi.org/10.3200/JOEB.82.1.11-19

Hanson, W. E., Creswell, J. W., Clark, V. L. P., Petska, K. S., \& Creswell, J. D. (2005). Mixed methods research designs in counseling psychology. Journal of Counseling Psychology, 52(2), 224235. https://doi.org/10.1037/0022-0167.52.2.224

Harmer, J. (2007). The Practice of English Language Teaching (4th ed.). Harlow, United Kingdom: Pearson Education Limited.

Lee, D., Morrone, A. S., \& Siering, G. (2018). From swimming pool to collaborative learning studio: Pedagogy, space, and technology in a large active learning classroom. Educational Technology Research \& Development, 66(1), 95-127. https://doi.org/10.1007/s11423-017-9550-1

McPherson, M., Smith-Lovin, L., \& Cook, J. M. (2001). Birds of a Feather: Homophily in Social Networks. Annual Review of Sociology, 27(1), 415-444. https://doi.org/10.1146/annurev.soc.27.1.415

Monohan, T. (2002). Flexible Space \& Built Pedagogy: Emerging IT Embodiments. Inventio, 4(1), 1 19.

Morrone, A., Flaming, A., Birdwell, T., Russell, J., Roman, T., \& Jesse, M. (2017). Creating active learning classrooms is not enough: Lessons from two case studies. EDUCASE Review. Retrieved from https://er.educause.edu/articles/2017/12/creating-active-learningclassrooms-is-not-enough-lessons-from-two-case-studies

O'Cathain, A., Murphy, E., \& Nicholl, J. (2008). The quality of mixed methods studies in health services research. Journal of Health Services Research \& Policy, 13(2), 92-98.

Orr, D. W. (2004). Earth in mind: On education, environment, and the buman prospect (2nd ed.). Washington, DC: Island Press.

Park, E., \& Choi, B. (2014). Transformation of classroom spaces: traditional versus active learning classroom in colleges. Higher Education, 68(5), 749-771. https://doi.org/10.1007/s10734$\underline{014-9742-0}$

Journal of the Scholarship of Teaching and Learning, Vol. 20, No. 3, December 2020. josotl.indiana.edu 
Paul Baepler, \& Walker, J. D. (2014). Active Learning Classrooms and Educational Alliances: Changing Relationships to Improve Learning. New Directions for Teaching and Learning, 2014(137), 27-40. https://doi.org/10.1002/tl.20083

Poellhuber, B., Fournier St-Laurent, S., \& Roy, N. (2018). Using the TAM and Functional Analysis to Predict the Most Used Functions of an Active Learning Classroom (ALC). Frontiers in ICT, 5(8). https://doi.org/10.3389/fict.2018.00008

Pratton, J., \& Hales, L. W. (1986). The Effects of Active Participation in Student Learning. Journal of Educational Research, 79(4), 210-215. https://doi.org/10.1080/00220671.1986.10885679

Ramsay, C. M., Guo, X., \& Pursel, B. K. (2017). Leveraging Faculty Reflective Practice to Understand Active Learning Spaces: Flashbacks and Re-Captures. Journal of Learning Spaces, 6(3), 42-53.

Rands, M. L., \& Gansemer-Topf, A. M. (2017). "The room itself is active": How classroom design impacts student engagement. 2017, 6(1).

Ricke, A. (2019). Enhancing classroom interaction: The integration of image-sharing projection software in social science and humanities classrooms. Interactive Learning Environments. https://doi.org/10.1080/10494820.2019.1652834

Saul, J. M., Deardorff, D. L., Abbott, D. S., Allain, R. J., \& Beichner, R. J. (2000). Evaluating Introductory Physics Classes in Light of the ABET Criteria: An Example from the SCALE-UP Project. Retrieved from http://search.ebscohost.com/login.aspx?direct $=$ true\&db=eric\&AN=ED459063\&site $=$ ehos t-live

Scrivener, J. (2011). Learning Teaching: The Essential Guide to English Language Teaching. Oxford: Macmillan Publishers.

Shimazoe, J., \& Aldrich, H. (2010). Group Work Can Be Gratifying: Understanding \& Overcoming Resistance to Cooperative Learning. College Teaching, 58(2), 52-57. https://doi.org/10.1080/87567550903418594

Siemens, G. (2008). New structures and spaces of learning: The systemic impact of connective knowledge, connectivism, and networked learning. Retrieved from http://elearnspace.org/Articles/systemic_impact.htm

Smith, C. V., \& Cardaciotto, L. (2011). Is Active Learning Like Broccoli? Student Perceptions of Active Learning in Large Lecture Classes. Journal of the Scholarship of Teaching and Learning, 11(1), 53-61.

Stoltzfus, J. R., \& Libarkin, J. (2016). Does the Room Matter? Active Learning in Traditional and Enhanced Lecture Spaces. CBE life sciences education, 15(4), ar68. https://doi.org/10.1187/cbe.16-03-0126

Stone, R., Cooper, S., \& Cant, R. (2013). The value of peer learning in undergraduate nursing education: a systematic review. ISRN Nurs, 2013, 930901. https://doi.org/10.1155/2013/930901

Strauss, A. L. (1987). Qualitative analysis for social scientists. New York, NY: Cambridge University Press.

Tavakol, M., \& Dennick, R. (2011). Making sense of Cronbach's alpha. International Journal of Medical Education, 2, 53-55. https://doi.org/10.5116/ijme.4dfb.8dfd

U.S. Department of Education. (2016). 2016 National Education Technology Plan. Retrieved from https://tech.ed.gov/netp/introduction/

Van Horne, S., \& Murniati, C. T. (2016). Faculty adoption of active learning classrooms. Journal of Computing in Higher Education, 28(1), 72-93. https://doi.org/10.1007/s12528-016-9107-z

Walker, J. D., Brooks, D. C., \& Baepler, P. (2011). Pedagogy and Space: Empirical Research in New Learning Environments. Educause Quarterly, 34(4).

Journal of the Scholarship of Teaching and Learning, Vol. 20, No. 3, December 2020. josotl.indiana.edu 
Warren, M. J. C. (2016). Teaching with Technology: Using Digital Humanities to Engage Student Learning. In (Vol. 19, pp. 309-319): Wiley-Blackwell.

Weinstein, C. S. (1979). The Physical Environment of School: A Review of the Research. Review of Educational Research, 49(4), 577-610.

Williams, K., Childers, C., \& Kemp, E. (2013). Stimulating and Enhancing Student Learning Through Positive Emotions. Journal of Teaching in Travel \& Tourism, 13(3), 209-227. https://doi.org/10.1080/15313220.2013.813320

Williamson, S. N. (2007). Development of a self-rating scale of self-directed learning. Nurse Res, 14(2), 66-83. https://doi.org/10.7748/nr2007.01.14.2.66.c6022

Journal of the Scholarship of Teaching and Learning, Vol. 20, No. 3, December 2020.

josotl.indiana.edu 